ORIGINAL ARTICLE

\title{
Antioxidant and hepatoprotective effects of ethano- lic and ethyl acetate stem bark extracts of Copaifera multijuga (Fabaceae) in mice
}

\author{
Débora Linsbinski PEREIRA¹, Ana Paula Simões DA CUNHA², Cássia Regina Primila CARDOSO², \\ Cláudia Quintino DA ROCHA³, Wagner VILEGAS ${ }^{4}$, Adilson Paulo SINHORIN ${ }^{1}$, \\ Valéria Dornelles Gindri SINHORIN ${ }^{*}$ \\ Universidade Federal de Mato Grosso, Instituto de Ciências Naturais, Humanas e Sociais, Programa de Pós Graduação em Ciências Ambientais (PPGCAM), Campus \\ de Sinop, Mato Grosso, Brazil \\ 2 Universidade Federal de Mato Grosso, Instituto de Ciências da Saúde, Campus de Sinop, Mato Grosso, Brazil \\ 3 Universidade Federal do Maranhão, Departamento de Química, Centro Tecnológico, Maranhão, Brazil \\ ${ }^{4}$ Universidade Estadual Paulista Júlio de Mesquita Filho, Unidade São Vicente, São Paulo, Brazil \\ * Corresponding author: valeriadgindri@gmail.com
}

\begin{abstract}
The properties of oil-resin of copaiba, Copaifera multijuga are commonly mentioned in the literature, but there are few studies on extracts from its stem bark. We evaluated the antioxidant effects of ethanolic (EE) and ethyl acetate (EA) crude stem bark extracts from copaiba and compared them to rutin in a paracetamol (PCM)-induced oxidative stress model in mice. All test comparisons differed significantly. Hepatic catalase (CAT) and glutathione- $S$-transferase (GST) activity decreased in the PCM group, and there was an increase of protein carbonyls in the liver, kidney and brain. However, the protein carbonyls decreased in the liver for the PCM + EE group, in the kidneys for the PCM + EA and PCM + Rutin groups, and in the brain for all treatments. Hepatic GSH decreased in the PCM group and increased in the PCM + EE group. The extracts showed a positive effect on ascorbic acid (ASA), since they were able to restore the levels of parameters that had been changed by PCM. There was an increase of ALT and AST activity in the plasma within the PCM group. Even though ALT decreased in the PCM + Rutin, $\mathrm{PCM}+\mathrm{EE}$ and PCM + EA groups, EE and EA did not have an effect on AST. The strongest antioxidant effect was observed for $\mathrm{EE}$, due to the presence of the phenolic compounds epicatechin and epiafzelechin, as well as the highest concentration of total phenols and an excellent antioxidant potential observed in the DPPH. test.
\end{abstract}

KEYWORDS: oxidative stress, acute intoxication, acetaminophen, copaiba

\section{Efeitos antioxidante e hepatoprotetor dos extratos brutos etanólico e acetato de etila da casca do caule da Copaifera multijuga (Fabaceae) em camundongos}

\section{RESUMO}

As propriedades do óleo-resina da copaíba, Copaifera multijuga são comumente citadas na literatura, mas há poucos estudos sobre extratos da casca do caule. Avaliamos os efeitos antioxidantes de extratos brutos etanólico (EE) e acetato de etila (EA) da casca do caule da copaíba e os comparamos à rutina no modelo de estresse oxidativo induzido por paracetamol (PCM) em camundongos. Todas as comparaçôes de teste diferiram significativamente. A atividade da catalase hepática (CAT) e da glutationa-S-transferase (GST) diminuiu no grupo PCM, e houve um aumento de proteínas carboniladas no fígado, rim e cérebro. No entanto, as proteínas carboniladas diminuíram no fígado para o grupo PCM + EE, nos rins para os grupos PCM + EA e PCM + rutina, e no cérebro para todos os tratamentos. A GSH hepática diminuiu no grupo PCM e aumentou no grupo PCM + EE. Os extratos mostraram um efeito positivo sobre o ácido ascórbico (ASA), uma vez que foram capazes de restaurar os níveis dos parâmetros que foram alterados pelo PCM. Houve um aumento da atividade de ALT e AST no plasma dentro do grupo PCM. Embora a ALT tenha diminuído nos grupos PCM + rutina, PCM + EE e PCM + EA, EE e EA não afetaram a AST. O efeito antioxidante mais forte foi observado para o EE, provavelmente devido à presença dos compostos fenólicos epicatequina e epiafzelequina, assim como à maior concentração de fenóis totais e um excelente potencial antioxidante observado no teste DPPH.

PALAVRAS-CHAVE: estresse oxidativo, intoxicação aguda, acetaminofeno, copaíba

CITE AS: Pereira, D.L.; da-Cunha, A.P.S.; Cardoso, C.R.P.; da-Rocha, C.Q.; Vilegas, W.; Sinhorin, A.P.; Sinhorin, V.D.G. 2018. Antioxidant and hepatoprotective effects of ethanolic and ethyl acetate stem bark extracts of Copaifera multijuga (Fabaceae) in mice. Acta Amazonica 48: $347-357$. 


\section{INTRODUCTION}

The Brazilian National Toxic-Pharmacological Information System (SINITOX) cites inappropriate use of medications as the main cause of human poisoning in Brazil (Brasil 2011), which may be due to self-medication, lack of knowledge about the toxicity of drugs, or overintake for suicidal purpose. Paracetamol (PCM) is an analgesic and antipyretic and is one of the most widely used drugs, being considered safe at therapeutic doses (Ozcelik et al. 2014). However, overdosage of PCM can cause hepatotoxicity associated with centrilobular necrosis (Hinson et al. 2010) and is often associated with renal damage (Ghosh and Sil 2007). The hepatotoxic effect of high doses of PCM is caused by the reactive metabolite $\mathrm{N}$-acetyl-pbenzoquinoneimine (NAPQI), which oxidizes cellular thiols (Basu et al. 2014). High concentrations of NAPQI reduce glutathione (GSH) levels and cause oxidative stress in the liver (Kisaoglu et al. 2014) and kidney (Manimaran et al. 2010).

The normal cell physiology or the redox homeostasis of mammalian cells is maintained by the endogenous antioxidant systems and by the absorption of dietary exogenous antioxidant agents (Pisoschi and Pop 2015). Medicinal plants and nutraceuticals or functional foods can be important sources of exogenous antioxidant compounds, such as phenolic compounds, $\beta$-carotene and ascorbic acid, which can aid endogenous antioxidant systems in preventing oxidative damage generated by excessive free radical production (Degáspari and Waszczynskyj 2004). The antioxidant activity exerted by phenolic compounds present in medicinal plants can decrease the citotoxicity of free radicals, preventing oxidative stress, cell damage and pathologies (Degáspari and Waszczynskyj 2004). In this context, the use of herbs and dietary supplements has increased greatly due to their purported beneficial effects on human health (Perlman et al. 2013).

Copaifera (Fabaceae) is a genus of tree species found throughout the tropics of Latin America, popularly known in Brazil as copaíba or pau-de-óleo (Leandro et al. 2012). Copaiba oil-resin contains of diterpenic acids and great amounts of sesquiterpenes (Veiga and Pinto 2002) and has been associated with anti-inflammatory (Paiva et al. 2004; Pieri et al. 2009; Veiga Junior et al. 2007; Gomes et al. 2010), topical analgesic (Carvalho et al. 2005), gastroprotective (Paiva et al.1998), antinociceptive (Gomes et al. 2007) and antitumoral activity (Gomes et al. 2008).

Copaifera multijuga Hayne is native to the Amazon region (Costa 2018). Its oil-resin is composed up to $90 \%$ of hydrocarbons and oxygenated sesquiterpenes to a lesser extent, also including a small amount of acidic diterpenes, and presents anti-inflammatory and anti-tumor properties (Lima $e t$ al. 2003; Gomes et al. 2008). The stem bark of C. multijuga is widely used in popular medicine, specially in northern Brazil, as a tea or in topical use, to treat ailments such as gastritis, inflammation, sore throat and stroke (Vásquez et al. 2014).

The overdosage with PCM can deplete glutathione and release proinflammatory agents, for instance, inflammatory cytokines (Karthivashan et al. 2015). Considering the widespread use of $C$. multijuga for treating inflammatory processes, we hypothesized that the stem bark extract from this species can exhibit antioxidant activitiy against PCM-induced oxidative stress. Thus, we aimed at evaluating the potential antioxidant effects exerted by ethanolic and ethyl acetate extracts from the stem bark of Copaifera multijuga against acute acetaminophen intoxication in mice.

\section{MATERIAL AND METHODS}

\section{Plant materials and botanical identification}

The stem bark from Copaifera multijuga was collected from one tree in Guarantã do Norte, state of Mato Grosso, Brazil (948'31.0'S, 5453'18.0”W). The specimen was identified by Ms. Ivani Kuntz Gonçalves from the Universidade Federal de Viçosa, and Dr. Haroldo Cavalcante de Lima from the Instituto de Pesquisa Jardim Botânico, Rio de Janeiro. A voucher specimen was deposited in the Herbarium of the Universidade Federal de Mato Grosso (UFMT), Sinop Campus (in Acervo Biológico da Amazônia Meridional ABAM, Sinop-MT, number 4801).

\section{Extract preparation and chemical analyses}

The extracts were obtained from $1.26 \mathrm{~kg}$ of stem bark dried at $40{ }^{\circ} \mathrm{C}$ and crushed. The extraction process occurred by maceration in three stages: first the material was macerated with $2 \mathrm{~L}$ hexane that yielded crude hexanic extract $(1.65 \mathrm{~g})$, second the material was macerated with $4 \mathrm{~L}$ ethyl acetate that yielded crude ethyl acetate extract (EA) $(5.15 \mathrm{~g})$, and third the material was extracted with $12 \mathrm{~L}$ ethanol that yielded crude ethanolic extract (EE) (220.46 g). In order to remove the solvent and concentrate the extract, samples were rotary evaporated under reduced pressure $(600 \mathrm{~mm} \mathrm{Hg})$ at $40{ }^{\circ} \mathrm{C}$. The EE and EA extracts were used in the biological studies because they had a greater amount of polar components than the hexane fraction.

Flow injection analysis (FIA) was performed using a Thermo Finnigan Fisher (San Jose, CA, USA) mass spectrometer equipped with an electro-spray ionization source, ion-trap analyzer and Xcalibur software for data processing (ESI-MS/MS) LTQXL. All lyophilized infusions were diluted and homogenized in $\mathrm{MeOH}: \mathrm{H}_{2} \mathrm{O}(8: 2 \mathrm{v} / \mathrm{v})$ at $5 \mathrm{ppm}$. The mass spectrometry analysis was performed following the methodology of Mesquita et al. (2017). The MS and MSn analyses in negative ion mode were selected at a flow rate of $5 \mu \mathrm{L} \cdot \mathrm{min}^{-1}$ and worked under the following conditions: capillary voltage $-25 \mathrm{~V}$, spray voltage $-5 \mathrm{kV}$, tube lens offset $75 \mathrm{~V}$, capillary temperature $275^{\circ} \mathrm{C}$, and a sheath gas (N2) 
flow rate 8 (arbitrary units). Mass spectra were recorded in the range $\mathrm{m} / \mathrm{z} 100-2000 \mathrm{Da}$. The first event was a full scan mass spectrum to acquire data on ions in the $\mathrm{m} / \mathrm{z}$ range. The second scan event was an MSn experiment performed using a data-dependent scan running on deprotonated molecules from the compounds at collision energy of 20\%-30\% and activation time of $30 \mathrm{~ms}$.

The quantity of total phenols in EE and EA was determined by the "Folin-Ciocalteu" reaction according to Woisky and Salatino (1998). The calibration curve was made with gallic acid $\left(0,1.5,2,2.5,3,3.5,4 \mu \mathrm{g} \mathrm{mL}^{-1}\right), 4 \mathrm{~mL}$ of Folin-Ciocalteu reagent $\left(2 \mathrm{~mol} \mathrm{~L}^{-1}\right)$ and $6 \mathrm{~mL}$ of $20 \%$ sodium carbonate in 50 $\mathrm{mL}$ of distilled water. $\mathrm{EE}$ and $\mathrm{EA}$ were solubilized in methanol solutions to a final concentration of $500 \mathrm{mg} \mathrm{mL}^{-1}$. Aliquots of $0.375 \mathrm{~mL}$ of the extracts, $4 \mathrm{~mL}$ of Folin-Ciocalteu reagent $\left(2 \mathrm{~mol} \mathrm{~L}^{-1}\right)$ and $6 \mathrm{~mL}$ of $20 \%$ sodium carbonate were added to $50 \mathrm{~mL}$ of distilled water. After 2 hours of reaction, we performed a reading in a spectrophotometer at $760 \mathrm{~nm}$. The result was compared to the calibration curve and expressed in mg gallic acid equivalent per gram of extract $\left(\mathrm{mgGAE} \mathrm{g}^{-1}\right)$.

The quantity of total flavonoids in EE and EA was determined by the reaction with aluminum chloride $\left(\mathrm{AlCl}_{3}\right)$ according to Woisky and Salatino (1998), with some adaptations. A calibration curve was constructed using methanolic solution of quercetin in concentrations of 0.25 , $0.50,1.0,1.5,2.5,3,3.5,4,4.5 \mathrm{mg} \mathrm{mL}^{-1}$ and $50 \mathrm{mg}$ of $\mathrm{AlCl}_{3}$ were added to each curve point. The EA and EE samples were prepared with $100 \mu \mathrm{g} \mathrm{mL}^{-1}$ of the extracts and $\mathrm{AlCl}_{3}(50$ $\mathrm{mg})$. After 30 minutes of reaction, the samples were read in a spectrophotometer at $420 \mathrm{~nm}$. The result was compared to the calibration curve and expressed in $\mathrm{mg}$ of quercetin equivalent per gram of extract $\left(\mathrm{mgQE} \mathrm{g}^{-1}\right)$.

To evaluate the antioxidant potential, we followed the methodology of Sousa et al. (2007), with some adaptations. We carried out the monitoring of free radical DPPH. consumption in the UV-Vis spectrophotometer at a wavelength of $515 \mathrm{~nm}$. The standard rutin and ascorbic acid, as well as the samples of EE and EA, were diluted in methanol at concentrations of 2.5, 5.0, 10.0, 15.0, 20.0, 25.0 $\mu \mathrm{g} \mathrm{mL}^{-1}$ and added DPPH. $\left(36 \mu \mathrm{g} \mathrm{mL}^{-1}\right)$, and read in a spectrophotometer after 30 minutes of reaction.

The effective concentration $\left(\mathrm{EC}_{50}\right)$ required and the amount of antioxidant to scavenger $50 \%$ of the initial DPPH. were determined from a first-order exponential curve and absorbance values at all concentrations of the tested samples (EE and EA) and standards (rutin and ascorbic acid) were converted to a percentage of antioxidant potential (\% AP) as described by Souza et al. (2007).

\section{Animals and treatment}

Male Swiss mice, with an average weight of $33.4 \mathrm{~g}$, were obtained from UFMT/Cuiabá. The animals were divided into
8 groups of 8 individuals each, and were acclimated for 20 days with a photoperiod of 12 hours light/dark, temperature of $24 \pm 1^{\circ} \mathrm{C}$, relative humidity of $51 \pm 2 \%$, fed pelleted feed diet (Purina) and filtered water ad libitum.

After the acclimation period, the following treatments were established by oral administration: Group 1- Control (water); Group 2 - Rutin (antioxidant, $6 \mathrm{mg} \mathrm{kg}^{-1}$ ); Group 3 - paracetamol (acetaminophen - PCM, $250 \mathrm{mg} \mathrm{kg}^{-1}$ ); Group 4 - PCM + Rutin; Group 5 - PCM + EE; Group 6 - PCM + EA; Group 7 - EE (250 $\left.\mathrm{mg} \mathrm{kg}^{-1}\right)$; Group 8 - EA (250 $\left.\mathrm{mg} \mathrm{kg}^{-1}\right)$.

The selected dosage of PCM (250 mg kg-1), as well as the damage induction protocol, followed Olaleye and Rocha (2008), while the rutin dosage $\left(6 \mathrm{mg} \mathrm{kg}^{-1}\right)$ followed Hort et al. (2008), and the EE and EA dosages $\left(250 \mathrm{mg} \mathrm{kg}^{-1}\right)$ were established according to the Malone Hippocratic test (Malone 1983). The experiment started by using PCM or water orally (via gavage): G3, G4, G5 and G6 groups received PCM 250 $\mathrm{mg} \mathrm{kg}^{-1}$; and G1, G2, G7 and G8 groups received only water. After 3 hours of induction of injury with PCM, the groups were treated orally (via gavage) with: G2 and G4 received rutin ( $6 \mathrm{mg} \mathrm{kg}^{-1}$ in $0.01 \%$ Tween); G5 and G6 received EE and EA extract, respectively (250 $\mathrm{mg} \mathrm{kg}^{-1}$ in $0.01 \%$ Tween); G7 and G8 received EE and EA extract, respectively $(250 \mathrm{mg}$ $\mathrm{kg}^{-1}$ in $0.01 \%$ Tween); and G1 and G3 received only water with $0.01 \%$ Tween.

In a treatment period of seven days, the treatment groups received either rutin or extracts, and the control groups (G1 and G3) received drinking water $+0.01 \%$ Tween once daily. After 24 hours of the last dose of treatment, the animals were anesthetized with ketamine $50 \mathrm{mg} \mathrm{kg}^{-1}$, xilazine $2 \mathrm{mg}$ $\mathrm{kg}^{-1}$ and acepromazine $2 \mathrm{mg} \mathrm{kg}^{-1}$ (i.p.). Heart puncture was performed to collect blood with heparinized syringes. The tubes were centrifuged to obtain clear plasma samples, which were used for the analyses of ALT and AST. The animals were sacrificed, and their liver, kidneys and brain were removed and stored at $-85^{\circ} \mathrm{C}$. The study was authorized by protocol \# 23108.781869/12-0 of the Ethics Committee on Animal Research (CEPA), UFMT/Cuiabá.

\section{Biochemical analysis}

Superoxide dismutase (SOD) activity in the liver was measured according to Misra and Fridovich (1972). The result was expressed in UI SOD mg protein ${ }^{-1}$. Liver, brain and kidney catalase (CAT) activity was determined according to Nelson and Kiesow (1972). The change in absorbance of $\mathrm{H}_{2} \mathrm{O}_{2}$ in 60 seconds was measured in a spectrophotometer at $240 \mathrm{~nm}$ and expressed in $\mu \mathrm{mol} \mathrm{H}_{2} \mathrm{O}_{2} \mathrm{~min}^{-1} \mathrm{mg}$ protein ${ }^{-1}$. The activity of glutathione-S-transferase (GST) in the liver was determined according to Habig et al. (1974). The result was expressed as $\mu \mathrm{mol}$ GS-DNB $\mathrm{min}^{-1} \mathrm{mg}$ protein ${ }^{-1}$. The molar extinction coefficient was used for CDNB $9.6 \mathrm{mM} \mathrm{cm}^{-1}$. Reduced glutathione $(\mathrm{GSH})$ was measured in liver, brain and kidney following the method by Sedlack and Lindsay (1968). The 
result was expressed in $\mu \mathrm{mol} \mathrm{GSH} \mathrm{mg} \mathrm{protein}{ }^{-1}$. The formation of thiolate anion was determined at $412 \mathrm{~nm}$ and compared to a standard curve of GSH. The levels of ascorbic acid (ASA) in the liver and brain were determined according to Roe (1954). The result was expressed in $\mu$ mol ASA g ${ }^{-1}$ tissue. The protein carbonyl assay was performed in liver and kidney according to Yan et al. (1995) with some modifications. The absorbance was determined at $370 \mathrm{~nm}$. The amount of protein carbonyl was expressed in nmol carbonyl $\mathrm{mg}$ protein ${ }^{-1}$.

The protein content for SOD, CAT, GST, GSH and protein carbonyl was determined following the method by Bradford (1976) using bovine serum albumin as the standard for construction of the calibration curve. The samples were read at $595 \mathrm{~nm}$.

Dosages of the activities of alanine aminotransferase (ALT) and aspartate aminotransferase (AST) present in plasma were performed with commercial kits (Labtest', Diagnostics SA, Minas Gerais, Brazil).

\section{Statistical analysis}

The data were expressed as mean \pm standard deviation (SD) and analyzed by one way ANOVA followed by post hoc Tukey test. The results were considered statistically significant at $\mathrm{p}$ $<0.05$.

\section{RESULTS}

Five phenolic compounds were identified by mass spectrometry fingerprinting: (Epi) free chatechin and other four condensed tannins (Epichatechin-Epiafzelechin ((Epi) Cat-(Epi)Afz), compound 1; Epichatechin-EpiafzelechinEpiafzelechin ((Epi)Cat-(Epi)Afz-(Epi)Afz), compound 2;
Epichatechin-Epiafzelechin-Epiafzelechin-Epiafzelechin ((Epi)Cat-(Epi)Afz-(Epi)Afz-(Epi)Afz), compound 3; and Epichatechin-Epiafzelechin-Epiafzelechin-Epiafzelechin (Epi)Cat-(Epi)Afz-(Epi)Afz-(Epi)Afz-(Epi)Cat, compound 4) (Figures 1 and 2).

The total phenolic compounds and flavonoids in EE (643.43 $\mathrm{mgGAE} \mathrm{g}^{-1}$ and $11.53 \mathrm{mgQE} \mathrm{g}^{-1}$, respectively) were higher than those found in EA (187.21 $\mathrm{mgGAE} \mathrm{g}^{-1}$ and 8.60 $\mathrm{mgQE} \mathrm{g}^{-1}$, respectively) (Table 1 ). EE exhibited a higher antioxidant potential with lower $\mathrm{EC}_{50}\left(23 \mu \mathrm{g} \mathrm{mL}^{-1}\right)$, when compared to the standard rutin and ascorbic acid (30 and $35 \mu \mathrm{g} \mathrm{mL} \mathrm{m}^{-1}$, respectively), as well as when compared to EA $\left(91 \mu \mathrm{g} \mathrm{mL} \mathrm{m}^{-1}\right)$.

Hepatic SOD activity was not modified by the treatments (Figure 3A). However, PCM caused a significant decrease in CAT activity (22.8\%). The extracts or rutin had no effect on the hepatic CAT activity levels. But rutin, EE and EA attenuated the decrease in CAT activity produced by PCM (Figure 3B). GST, an important enzyme in the detoxification of xenobiotics, showed a significant reduction $(30.2 \%)$ of its activity in the PCM group in comparison to the control group (Figure 3C).

GSH, an important non-enzymatic antioxidant, decreased significantly by $22.8 \%$ in the PCM group when compared to the control group, and increased significantly by $35 \%$ in the $\mathrm{PCM}+\mathrm{EE}$ group when compared to the PCM group (Table 2). The ascorbic acid level decreased by $16.2 \%$ in the PCM group when compared with the control group. However, the animals treated with PCM + EE or PCM + EA exhibited a significant increase of $18.2 \%$ and $26.1 \%$, respectively when compared to the PCM group (Table 2). There was a significant

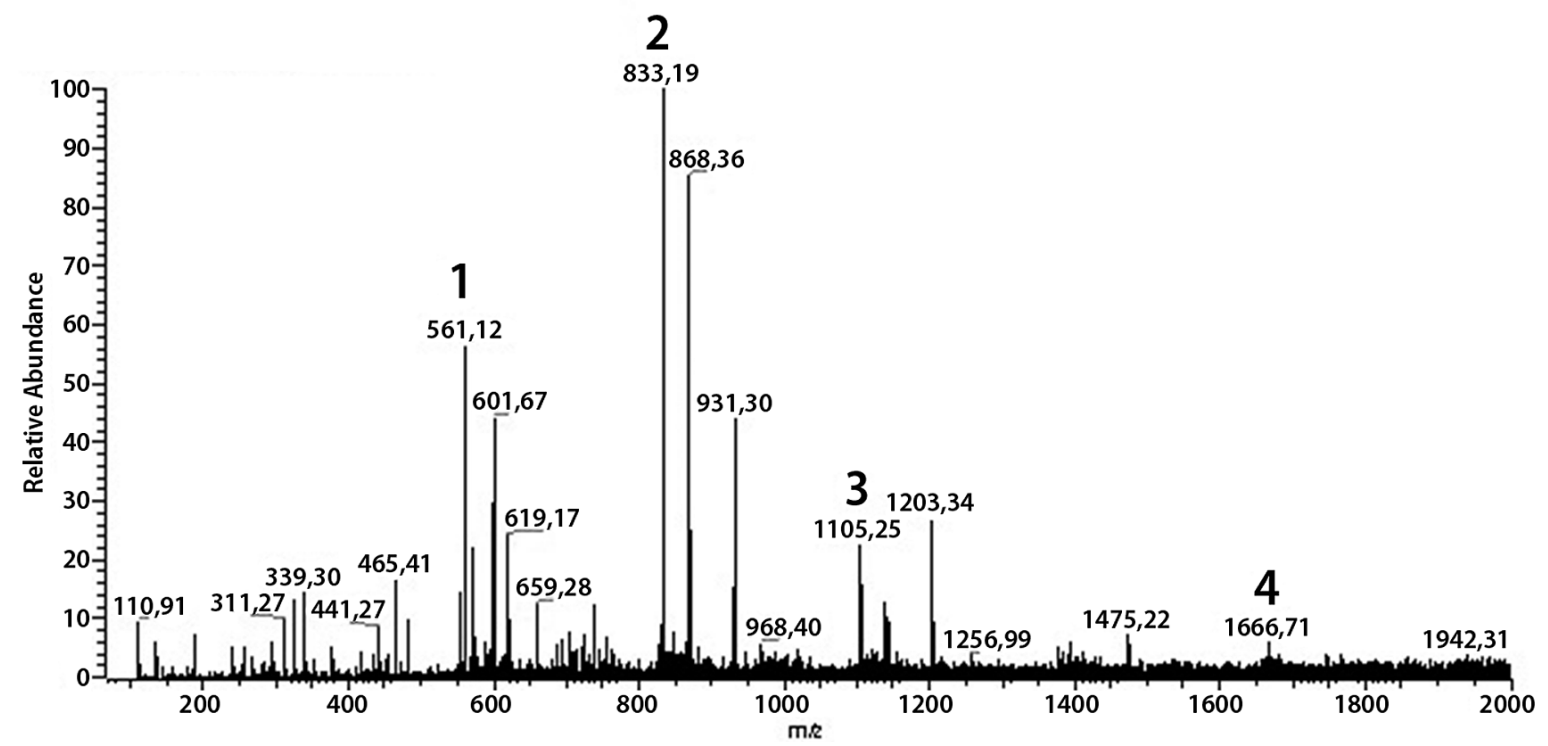

Figure 1. Direct-infusion ESI-IT-MS profile of crude ethanolic extract from Copaifera multijuga stem bark at negative ion ESI mode. 
<smiles>Oc1cc(O)c2c(c1)O[C@H](c1ccc(O)c(O)c1)C[C@H]2O</smiles>

epicatechin

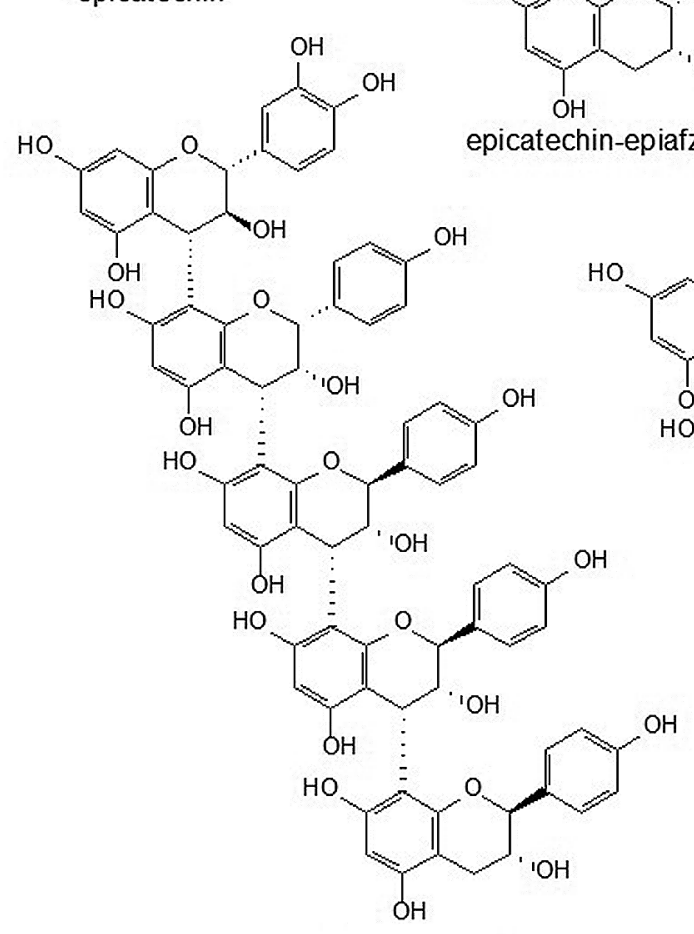

epicatechin-epiafzelechin-epiafzelechinepiafzelechin-epaiafzelecin (4)

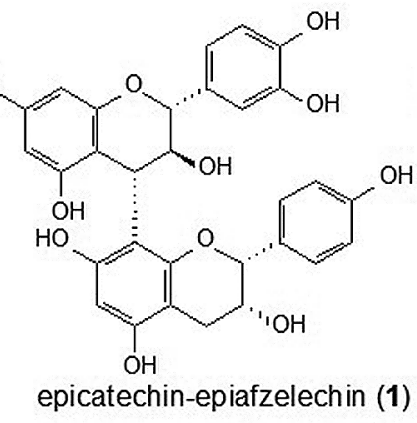<smiles>CCC(O)=C(O)CC</smiles>

epicatechin-epiafzelechinepiafzelechin (2)<smiles>O</smiles>

Figure 2. Structure of the compounds identified by ESI-IT-MS in crude ethanolic extract from Copaifera multijuga stem bark.

Table 1. Analysis of total phenols, total flavonoids and effective concentration $\left(E_{50}\right)$ of extracts of Copaifera multijuga stem bark. ASA: ascorbic acid; EE: ethanolic extract; EA: ethyl acetate extract; mg GAE/g: mg gallic acid equivalent per gram of extract; $m g$ QE/g: $m g$ of quercetin equivalent per gram of extract; $\mathrm{EC}_{50}$ : effective concentration required and the amount of antioxidant to scavenger $50 \%$ of the initial DPPH.

\begin{tabular}{lccc}
\hline Samples & $\begin{array}{c}\text { Total phenols } \\
(\mathrm{mg} \mathrm{GAE} / \mathrm{g})\end{array}$ & $\begin{array}{c}\text { Total flavonoids } \\
(\mathrm{mg} \mathrm{QE} / \mathrm{g})\end{array}$ & $\begin{array}{c}\mathrm{DPPH} \cdot \mathrm{EC}_{50}(\mu \mathrm{g} / \\
\mathrm{mL})\end{array}$ \\
\hline EE & 643.43 & 11.53 & 22.96 \\
EA & 187.21 & 8.60 & 91.13 \\
& & & 30.06 \\
Rutin & ------ & 35.74 \\
$\begin{array}{l}\text { Ascorbic acid } \\
\text { (ASA) }\end{array}$ & & & \\
\hline
\end{tabular}

Table 2. Effect of ethanolic (EE) and ethyl acetate (EA) extracts of Copaifera multijuga stem bark under oxidative stress induced by paracetamol/ acetaminophen (PCM) in liver tissue. Results are expressed as mean $\pm S D ; n=8$ animals. ${ }^{a} p<0.05$ compared with the control group; ${ }^{b} p<0.05$ compared with the PCM group by one way ANOVA followed by a Tuckey test.

\begin{tabular}{lccc}
\hline Treatments & $\begin{array}{c}\text { GSH } \\
(\mu \mathrm{mol} \text { GSH mg } \\
\left.\text { protein }{ }^{-1}\right)\end{array}$ & $\begin{array}{c}\text { ASCORBIC ACID } \\
\left(\mu \mathrm{mol} \mathrm{ASA} \mathrm{g}{ }^{-1}\right. \\
\text { tissue })\end{array}$ & $\begin{array}{c}\text { CARBONYL } \\
\left(\begin{array}{c}\text { (mol carbonyl } \\
\left.\text { mg protein }^{-1}\right)\end{array}\right.\end{array}$ \\
\hline Control & $164.50 \pm 20.01$ & $1.05 \pm 0.10$ & $1.70 \pm 0.40$ \\
Rutin & $130.30 \pm 23.49$ & $1.05 \pm 0.10$ & $2.06 \pm 0.49$ \\
\hline PCM & $127.00 \pm 22.31^{\mathrm{a}}$ & $0.88 \pm 0.10^{\mathrm{a}}$ & $2.61 \pm 0.49^{\mathrm{a}}$ \\
PCM + Rutin & $145.10 \pm 13.38$ & $0.92 \pm 0.09$ & $1.98 \pm 0.37$ \\
\hline PCM + EE & $171.40 \pm 26.8 \mathrm{~b}$ & $1.04 \pm 0.09^{\mathrm{b}}$ & $1.46 \pm 0.35^{\mathrm{b}}$ \\
PCM + EA & $144.20 \pm 28.52$ & $1.11 \pm 0.11^{\mathrm{b}}$ & $2.07 \pm 0.36$ \\
\hline EE & $134.50 \pm 25.16$ & $0.93 \pm 0.06$ & $2.31 \pm 0.28$ \\
EA & $144.60 \pm 8.37$ & $1.15 \pm 0.07$ & $2.22 \pm 0.50$ \\
\hline
\end{tabular}




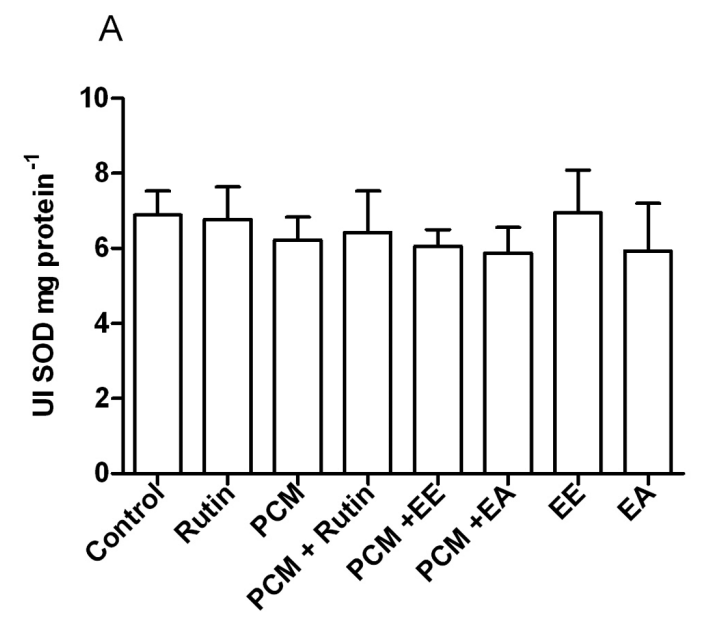

increase of $53.5 \%$ in protein carbonyls in the PCM group compared to the control group. PCM + EE significantly decreased by $44.1 \%$ the damage caused by the PCM (Table 2).

There was a significant increase in ALT in the plasma of animals treated with PCM (25.8\%), when compared to the control group. However, the ALT levels in plasma in the $\mathrm{PCM}+$ Rutin, $\mathrm{PCM}+\mathrm{EE}$ and PCM + EA groups decreased significantly $(35 \%, 21.7 \%$ and $28.6 \%$, respectively) when compared to the PCM group (Figure 4A). The plasma activity of AST significantly increased by about $65 \%$ in the PCM group when compared to the control group, and decreased significantly in the PCM + Rutin group (55.9\%) when compared to the PCM group. In contrast to ALT, however, EE and EA did not reverse this change in AST activity (Figure 4B).
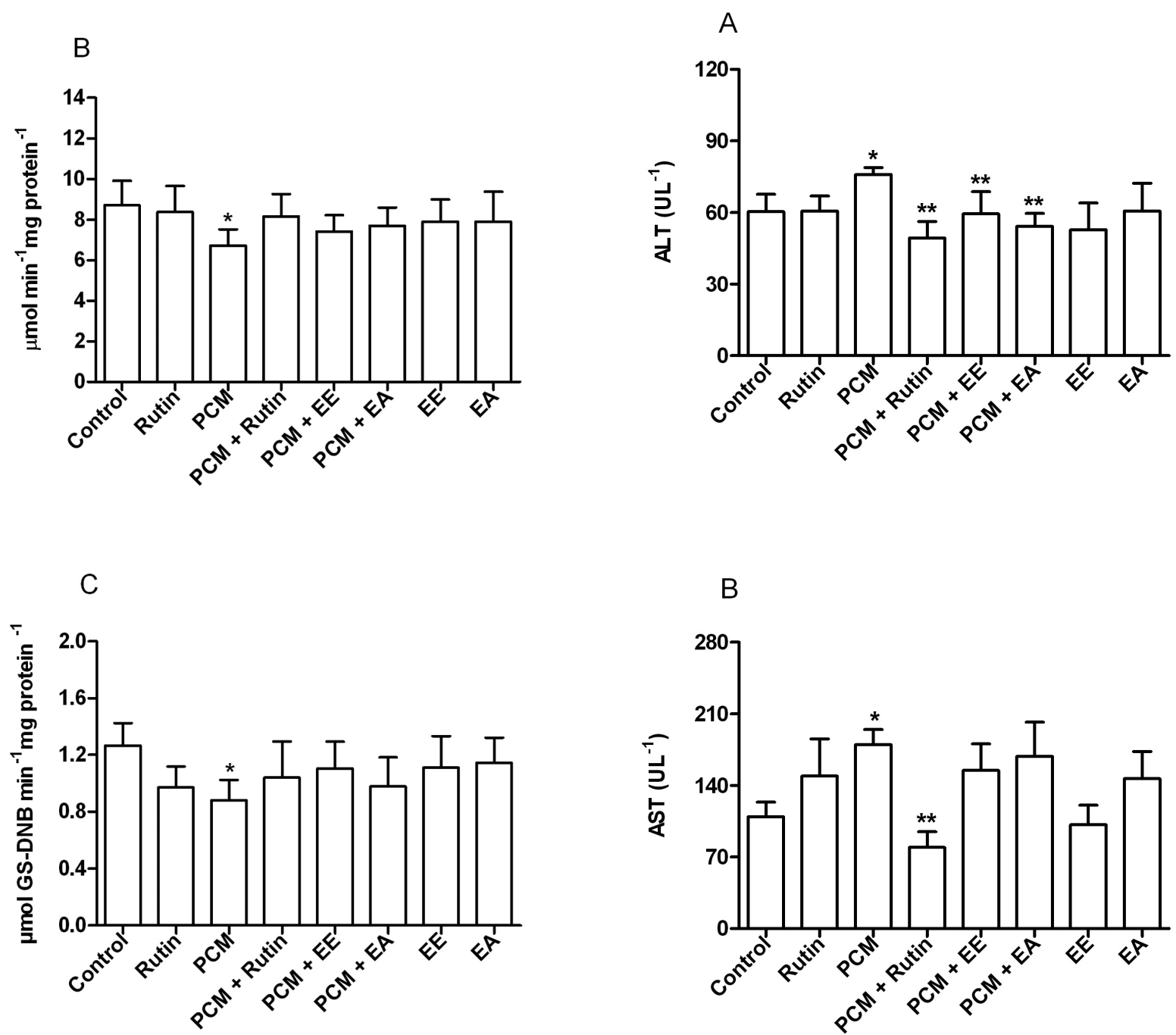

Figure 3. Effect of ethanolic (EE) and ethyl acetate (EA) extracts of Copaifera multijuga stem bark under oxidative stress induced by paracetamol/ acetaminophen (PCM) in liver tissue: A - SOD; B - CAT; C - GST. Results are expressed as mean $\pm S D ; n=8$ animals. " $p<0.05$ compared with the control group by one way ANOVA followed by a Tuckey test.

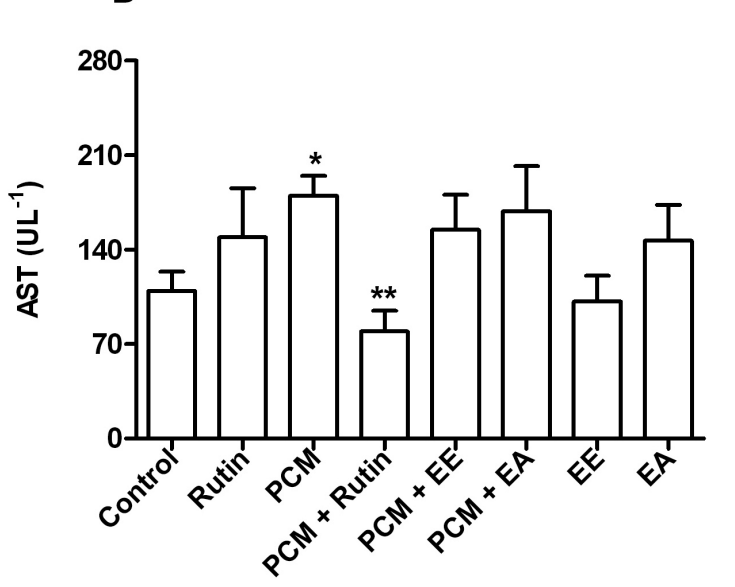

Figure 4. Effect of ethanolic (EE) and ethyl acetate (EA) extracts of Copaifera multijuga stem bark under oxidative stress induced by paracetamol/ acetaminophen (PCM) in the plasma: A - ALT and B - AST. Results are expressed as mean \pm SD; $n=7$ animals. " $p<0.05$ compared with the control group; "* $p<0.05$ compared with the PCM group by one way ANOVA followed by a Tuckey test. 
CAT activity was not altered in the kidney, but the nonenzymatic antioxidant GSH was significantly reduced by $43.3 \%$ in the PCM group when compared to the control. The positive control group (PCM) had an increase in protein carbonyls $(71.3 \%)$ when compared to the control group. However, the PCM + EA and PCM + Rutin groups had a significant decrease in the carbonylation of $50.7 \%$ and $30.4 \%$, respectively (Table 3).

CAT activity and GSH levels were not altered in the brains of mice exposed to PCM. However, the level of ASA was significantly increased in the EE group (by $42 \%$ ) when compared to the control group, showing an effect perse (Table 4). Protein carbonylation increased significantly by $28.5 \%$ in the positive control group (PCM) when compared to the control group, while the PCM + EE, PCM + EA and PCM + Rutin groups reduced this parameter $(38.7 \%, 35.7 \%, 31.5 \%$, respectively) when compared to the PCM group. In the EE group the carbonylation of proteins in the brain tissue was significantly reduced (by $42.3 \%$ ), when compared to the control group (Table 4).

Table 3. Effect of ethanolic (EE) and ethyl acetate (EA) extracts of Copaifera multijuga stem bark under oxidative stress induced by paracetamol/ acetaminophen (PCM) in kidney tissue. Results are expressed as mean $\pm S D ; n=$ 8 animals. ${ }^{a} p<0.05$ compared with the control group; ${ }^{b} p<0.05$ compared with the PCM group by one way ANOVA followed by a Tuckey test.

\begin{tabular}{|c|c|c|c|}
\hline Treatments & $\begin{array}{c}\text { CAT } \\
\left(\mu \mathrm{mol} \mathrm{H}_{2} \mathrm{O}_{2} \mathrm{~min}^{-1}\right. \\
\left.\text { mg protein }^{-1}\right)\end{array}$ & $\begin{array}{c}\text { GSH } \\
(\mu \mathrm{mol} G S H \text { mg } \\
\left.\text { protein }^{-1}\right)\end{array}$ & $\begin{array}{c}\text { CARBONYL } \\
\text { (nmol carbonyl } \\
\text { mg protein }{ }^{-1} \text { ) }\end{array}$ \\
\hline Control & $28.35 \pm 4.84$ & $61.45 \pm 14.30$ & $3.21 \pm 0.76$ \\
\hline Rutin & $25.22 \pm 3.81$ & $45.76 \pm 14.83$ & $4.35 \pm 0.63$ \\
\hline PCM & $25.67 \pm 3.02$ & $34.86 \pm 9.77^{a}$ & $5.50 \pm 1.20^{\mathrm{a}}$ \\
\hline PCM + Rutin & $23.45 \pm 3.57$ & $48.52 \pm 9.48$ & $3.83 \pm 0.78^{b}$ \\
\hline $\mathrm{PCM}+\mathrm{EE}$ & $25.96 \pm 1.43$ & $49.85 \pm 8.80$ & $4.88 \pm 1.02$ \\
\hline$P C M+E A$ & $26.22 \pm 2.85$ & $52.61 \pm 13.50$ & $2.71 \pm 0.62^{b}$ \\
\hline EE & $25.81 \pm 1.73$ & $49.44 \pm 11.94$ & $3.75 \pm 0.82$ \\
\hline EA & $26.44 \pm 2.45$ & $45.42 \pm 6.22$ & $4.31 \pm 0.63$ \\
\hline
\end{tabular}

\section{DISCUSSION}

The effects observed in vivo in this study in the EE groups can be related to the phenolic compounds detected in the EE extract of C. multijuga, mainly the tannins (Shimoda et al. 2008). The presence of free (Epi) catechin at $\mathrm{m} / \mathrm{z} 289$ is in accordance with Nuengchamnong et al. (2009). Condensed tannins were also detected, such as dimers (compound 1 at $\mathrm{m} / \mathrm{z} 561.12$ ), the ion found at $\mathrm{m} / \mathrm{z} 833.19$ that corresponds to trimer compound 2 , and the ion at $\mathrm{m} / \mathrm{z} 1105.25$ (which can be attributed to compound 3), all of them in line with Souza et al. (2008). We suggest that $\mathrm{m} / \mathrm{z} 1666.71$ corresponds to a tannin with higher polymerization (corresponding to compound 4), but no data was found in the literature for this compound, since most of the equipment used for this type of analysis does not detect compounds with track acquisition at $100-1500 \mathrm{~m} / \mathrm{z}$.

PCM is a drug that can cause toxicity at high doses by inducing oxidative stress in the liver and kidney. The toxic metabolite of PCM (NAPQI) is conjugated with reduced glutathione, thereby reducing the concentration of GSH. With the depletion of GSH, there is an increase in the formation of nitrogen and oxygen reactive species in the liver and kidney (Stern et al. 2005; Hinson et al. 2010) thus causing mitochondrial oxidative stress (Hodgman and Garrard 2012).

The use of natural products containing antioxidant compounds, such as phenolic compounds, can effectively protect against the toxicity of the PCM metabolite (Jaeschke et al. 2011). The ethanolic extract from Copaifera multijuga stem bark showed higher concentration of total phenols and flavonoids, and significantly higher antioxidant potential than the ethyl acetate extract. This can be explained by the presence of phenolic compounds in the ethanolic extract, such as the tannins epicatechin and epiafzelechin, which were extracted in larger quantities by ethanol. In the chromatographic profile of the hydroalcoholic extract from Copaifera langsdorffi leaves at $257 \mathrm{~nm}$, the presence of phenolic compounds such as Quercetin-3-O- $\alpha$-L-rhamnopyranoside (quercitrin) and kaempferol-3-O- $\alpha$-L-rhamnopyranoside (afzelin) was

Table 4. Effect of ethanolic (EE) and ethyl acetate (EA) extracts of Copaifera multijuga stem bark under oxidative stress induced by paracetamol/acetaminophen (PCM) in brain tissue. Results are expressed as mean $\pm S D ; n=8$ animals. ${ }^{a} p<0.05$ compared with the control group; ${ }^{b} p<0.05$ compared with the PCM group by one way ANOVA followed by a Tuckey test.

\begin{tabular}{lcccc}
\hline Treatments & $\begin{array}{c}\text { CAT } \\
\left(\mu \mathrm{mol} \mathrm{H} 2 \mathrm{O} \mathrm{min}^{-1} \mathrm{mg} \mathrm{protein}^{-1}\right)\end{array}$ & $\begin{array}{c}\text { GSH } \\
\left(\mu \mathrm{mol} \mathrm{GSH} \mathrm{mg} \mathrm{protein}{ }^{-1}\right)\end{array}$ & $\begin{array}{c}\text { ASCORBIC ACID } \\
\left.(\mu \mathrm{mol} \mathrm{ASA} \mathrm{g})^{-1}\right)\end{array}$ & $\begin{array}{c}\text { CARBONYL } \\
\left(\mathrm{nmol} \mathrm{carbonyl} \mathrm{mg} \mathrm{protein}{ }^{-1}\right)\end{array}$ \\
\hline Control & $5.91 \pm 0.94$ & $87.22 \pm 14.06$ & $0.52 \pm 0.06$ & $4.32 \pm 0.46$ \\
Rutin & $5.53 \pm 0.78$ & $93.88 \pm 16.55$ & $0.62 \pm 0.06$ & $4.05 \pm 0.56$ \\
PCM & $6.29 \pm 0.85$ & $88.54 \pm 16.78$ & $0.54 \pm 0.08$ & $5.55 \pm 0.80^{\mathrm{a}}$ \\
PCM + Rutin & $5.95 \pm 1.10$ & $86.30 \pm 10.56$ & $0.70 \pm 0.10$ & $3.81 \pm 0.63^{b}$ \\
PCM + EE & $6.01 \pm 0.68$ & $82.36 \pm 9.04$ & $0.66 \pm 0.11$ & $3.40 \pm 0.80^{b}$ \\
PCM + EA & $6.27 \pm 1.15$ & $78.88 \pm 10.76$ & $0.64 \pm 0.10$ & $3.57 \pm 0.63^{b}$ \\
EE & $6.51 \pm 0.92$ & $80.24 \pm 10.26$ & $0.74 \pm 0.06^{\mathrm{a}}$ & $3.20 \pm 0.76^{\mathrm{a}}$ \\
EA & $5.85 \pm 1.12$ & $94.83 \pm 11.34$ & $0.60 \pm 0.04$ & $4.30 \pm 0.70$ \\
\hline
\end{tabular}


observed (Alves et al. 2013). In the chromatographic study of the ethanolic extract from $C$. langsdorffii pulp, the presence of epicatechingallate, catechin, epicatechin and other phenolic compounds was observed (Batista et al. 2016).

The toxic metabolite NAPQI is inactivated by GSTmediated conjugation with GSH (Mohar et al. 2014). GST is an important enzyme in the detoxification of xenobiotics, and showed lower activity in the group exposed to acute poisoning by PCM, indicating that PCM induced an inactivation of GST. The inhibition of GST, in association with a depletion of GSH, certainly contributed to worsening the hepatic damage caused by PCM. It is notable that the EE restored the GSH in higher levels than rutin, indicating a potential mechanism of protection of $C$. multijuga EE extract against PCM, which is possibly associated with its high concentration of total phenolics.

In some situations the organism may respond to the generation of free radicals by increasing the synthesis of antioxidant enzymes (Bianchi and Antunes 1999). However, in our study the enzymatic antioxidant defense system in hepatic tissue was reduced by PCM. The treatments with extracts and rutin (antioxidant control) did not change these parameters. The decrease in CAT, which was in accordance with literature (Olaleye and Rocha 2008; Olaleye et al. 2014; Shanmugam et al. 2013), can increase the $\mathrm{H}_{2} \mathrm{O}_{2}$ levels. In this context, this substance, together with the reactive NAPQI, can intensify the hepatic damage caused by PCM (Olaleye and Rocha 2008), promoting a covalent binding of NAPQI to cellular target proteins, starting the initial phase of PCM toxicity (Jaeschke et al. 2011). The increase in the levels of protein carbonylation observed in our study can also be associated with these changes. On the other hand, the SOD enzyme, which acts on the conversion of the superoxide radical $\left(\mathrm{O}_{2}-\right)$ into hydrogen peroxide $\left(\mathrm{H}_{2} \mathrm{O}_{2}\right)$, was not modified by PCM. Animals treated with $300 \mathrm{mg} \mathrm{kg}^{-1}$ of PCM had MnSOD levels restored after 6 hours of injury (Agarwal et al. 2011). However, in another study total SOD activity was reduced by PCM (Olaleye and Rocha 2008).

Many studies suggest that PCM is hepatotoxic when administered at high doses (Hinson et al. 2010; Hodgman et al. 2012; Kisaoglu et al. 2014) and some liver enzymes were analysed in order to confirm this damage. The hepatotoxic damage of PCM was confirmed by the increase of ALT and AST in plasma, which was also observed in other studies using PCM in the same dose $\left(250 \mathrm{mg} \mathrm{kg}^{-1}\right)$ (Olaleye and Rocha 2008) and higher doses [Rosa et al. 2012 (600 mg $\left.\mathrm{kg}^{-1}\right)$; Shanmugam et al. 2013 (800 $\left.\mathrm{mg} \mathrm{kg}^{-1}\right)$; Kisaoglu et al. $2014\left(1 \mathrm{~g} \mathrm{~kg}^{-1}\right)$; Olaleye et al. $2014\left(2 \mathrm{~g} \mathrm{~kg}^{-1}\right)$; and Verma et al. $\left.2013\left(3 \mathrm{~g} \mathrm{~kg}^{-1}\right)\right]$. EE, EA and rutin were able to reverse the damage caused by PCM on ALT, an enzyme found in the cytoplasm of hepatocytes (Nelson and Cox 2011), suggesting that they may act as hepatoprotectives. Although the extracts were not effective on AST, an important enzyme located in mitochondria (Nelson and Cox 2011), it is possible that the extracts did not have a pronounced antioxidant activity, which could be sufficient to protect the mitochondrial membrane.

In order to evaluate the protective effects of extracts against PCM-induced oxidative stress, we reported here whether EE and EA extracts had hepatotoxic properties. There was no evidence of any change in aminotransferase activity in the extract groups when compared to the control group. In a study about copaiba oleo-resin with a dose of $0.63 \mathrm{~mL} \mathrm{~kg}^{-1}$, there was a decrease in serum levels of ALT and AST (Nuguchi et al. 2002). It can thus be concluded that both the oleo-resin (at $\left.0.63 \mathrm{~mL} \mathrm{~kg}^{-1}\right)$ and the stem bark extract (EE and EA at $250 \mathrm{mg} \mathrm{kg}^{-1}$ ) are likely not hepatotoxic in rodents.

NAPQI can reach a high enough concentration in the kidney to react with the nucleophilic cellular constituents (Nelson and Pearson 1990), causing proximal tubular necrosis (Oshima-Franco and Franco 2003). Glutathione detoxifies NAPQI both in the liver and kidneys (Mudge et al. 1978). The increase in protein carbonylation in renal tissue in the PCM group may have occurred due to depletion of GSH, triggering cell damage. However, EA and rutin attenuated the increase in protein carbonylation induced by PCM, indicating a protective effect of the $C$. multijuga bark extract against PCM overdosage.

Similarly to renal tissue, CAT activity and GSH were not altered in the brain tissue, yet there was an increase in protein carbonyls, though much lower when compared to liver and kidney tissues), where the toxic metabolite caused major damage by possibly reaching higher concentrations. All treatments were able to reduce the increase in protein carbonyls caused by PCM in the brain.

Non-enzymatic antioxidants are exogenous agents responsible for the inhibition and reduction of injuries caused by free radicals in cells, and include ascorbic acid, $\alpha$-tocopherol, $\beta$-carotene, polyphenols and flavonoids (Ighodaro and Akinloye 2017). Ascorbic acid has a significant antioxidant action in the extracellular fluids, and contributes to the regeneration of $\alpha$-tocopherol from tocoferoxil radical, preserving the antioxidant capacity of biological membranes, as well as blocking off chain reactions and lipid peroxidation (Augusto 2006; Bianchi and Antunes 1999). The increasing effect of the extracts on the low level of ascorbic acid (ASA) in liver tissue depleated in the PCM group suggests that Copaifera multijuga can either stimulate the synthesis of this important non-enzymatic antioxidant or act as an antioxidant in mice. Although PCM did not cause any changes in ASA levels in brain tissue, EE per se had an important role in increasing ASA levels, which can contribute to the protection of tissues against free radicals produced by the body itself. 


\section{CONCLUSIONS}

Paracetamol overdosage caused liver damage in mice, as evidenced by the increase of ALT and AST in plasma. Oxidative stress caused by PCM was due to the depletion of GSH, reduced activity of CAT and GST and reduction in ASA. These events caused an increase in protein carbonylation, particularly in the hepatic tissue. The kidney was also affected because there was an increase in protein carbonylation and a depletion of GSH. Brain tissue damage occured due to the increase in protein carbonylation. The ethanolic (EE) and ethyl acetate (EA) crude stem bark extracts of Copaiba multijuga did not cause hepatotoxic and nephrotoxic effects and reduced several of the toxic effects caused by PCM overdosage. The EE had a generally better effect in most analyses when compared to EA and rutin, probably because of its higher concentration of phenolic compounds, such as the tannins epicatechin and epiafzelechin. Our results should stimulate further studies on the safety of C. multijuga EE and EA in experimental models, to determine their potential use as therapeutic agents for PCM overdosage in humans.

\section{ACKNOWLEDGMENTS}

The authors express their gratitude to Coordenação de Aperfeiçoamento de Pessoal de Nível Superior (CAPES) and Fundaçáo de Amparo a Pesquisa do Estado de Mato Grosso (FAPEMAT) for granting the scholarships to D. L. Pereira and A. P. S. Cunha, respectively. We would also like to thank Ms. Ivani Kuntz Gonçalves, from Universidade Federal de Viçosa, and Dr. Haroldo Cavalcante de Lima, from the Instituto de Pesquisa Jardim Botânico, Rio de Janeiro for assisting in botanical identification. Dayana Schimidt Moore translated the manuscript.

\section{REFERENCES}

Agarwal, R.; MacMillan-Crow, L.A.; Rafferty, T.M.; Saba, H.; Roberts, D.W.; Fifer, E. K.; James, L.P.; Hinson, J.A. 2011. Acetaminophen-Induced Hepatotoxicity in Mice Occurs with Inhibition of Activity and Nitration of Mitochondrial Manganese Superoxide Dismutase. Journal of Pharmacology and Experimental Therapeutics, 337: 110-116.

Alves, J.M.; Munari, C.C.; Monteiro Neto, M.A.B.; Furtado, R.A.; Senedese, J.M.; Bastos, J.K.; Tavares, D.C. 2013. In vivo protective effect of Copaifera langsdorffii hydroalcoholic extract on micronuclei induction by doxorubicin. Journal Applied Toxicology, 33: 854-860.

Augusto, O. 2006. Radicais livres, bons, maus e naturais. 1.ed. Oficina de Texto, São Paulo, 120p.

Basu, S.; Haldar, N.; Bhattacharya, S.; Biswas, S.; Biswas, M. 2014. Hepatoprotective activity of Litchi chinensis leaves against paracetamolinduced liver damage in rats. Middle East Journal Scientific Research, 7: 292-296.

Batista, A.G.; Ferrari, A.S.; Cunha, D.C.; Silva, J.K.; Cazarin,C.B.B.; Correa, L.C.; Prado, M.A.; Carvalho-Silva, L.B.; Esteves,
E.A.; Maróstica Júnior, M.R. 2016. Polyphenols, antioxidants, and antimutagenic effects of Copaifera langsdorffi fruit. Food Chemistry, 197: 1153-1159.

Bianchi, M.L.P.; Antunes, L.M.G. 1999. Free radicals and the main dietary antioxidants. Revista Nutrição, 12: 123-130.

Bradford, M.M. 1976. A rapid and sensitive method for the quantification of microgram quantities of protein utilizing the principle of protein-dye binding. Analytical Biochemistry, 72: 248-254.

Brasil. 2011. Sistema Nacional de informações tóxico farmacológicas - SINITOX. (http://www.fiocruz.br/sinitox/cgi/cgilua.exe/sys/ start.htm?sid=386). Accessed on 13 Dic 2014.

Buege, J.A.; Aust, S.D. 1978. Microsomal lipid peroxidation. Methods in Enzymology, 52: 302-309.

Carvalho, J.C.T.; Cascon, V.; Possebon, L.S.; Morimoto, M.S.S.; Cardoso, L.G.V.; Kaplan, M.A.C.; Gilbert, B. 2005. Topical antiinflamatory and analgesic activities of Copaifera duckei Dwyer. Phytotherapy Research, 19: 946-950.

Costa, J.A.S. 2018. Copaifera in Flora do Brasil 2020 em construção. Jardim Botânico do Rio de Janeiro. (http://floradobrasil.jbrj.gov. br/reflora/floradobrasil/FB82967). Accessed on 02 Aug 2018.

Degáspari, C.H.; Waszczynskyj, N. 2004. Propriedades antioxidantes de compostos fenólicos. Revista Visão Acadêmica, 5: 33-40.

Ghosh, A.; Sil, P.C. 2007. Anti-oxidative effect of a protein from Cajanus indicus L. against acetaminophen-induced hepatonephrotoxicity. Journal of Biochemistry and Molecular Biology, 40: 1039-1049.

Gomes, N.M.; Rezende, C.M.; Fontes, S.P.; Matheus, M.E.; Fernandes, P.D. 2007. Antinociceptive activity of Amazonian Copaiba oils. Journal of Ethnopharmacology, 109: 486-492.

Gomes, N.M.; Rezende, C.M.; Fontes, S.P.; Hovell, A.M.C.; Landgraf, R.G.; Matheus, M.E.; Pinto, A.C.; Fernandes, P.D. 2008. Antineoplasic activity of Copaifera multijuga oil and fractions against ascitic and solid Ehrlich tumor. Journal of Ethnopharmacology, 119: 179-184.

Gomes, N.M.; Rezende, C.M.; Fontes, S.P.; Matheus, M.E.; Pinto, A.C.; Fernandes, P.D. 2010. Characterization of the antinociceptive and anti-inflammatory activities of fractions obtained from Copaifera multijuga Hayne. Journal of Ethnopharmacology, 128: 177-183.

Habig, W.H.; Pabst, M.J.; Jacoby, W.B. 1974. Glutathione $S$-transferase, the first enzymatic step in mercapturic acid formation. Journal of Biological Chemistry, 249: 7130-7139.

Hinson, J.A.; Roberts, D.W.; James, L.P. 2010. Mechanisms of acetaminophen-induced liver necrosis. Handbook of Experimental Pharmacology, 196: 369-405.

Hodgman, M.J.; Garrard, A.R. 2012. A Review of Acetaminophen Poisoning. Critical Care Clinics, 28: 499-516.

Hort, M. A.; Dalbó, S.; Brighente, I.M.C.; Pizzolatti, M.G.; Pedrosa, R.C.; Ribeiro do Valle, R.M. 2008. Antioxidant and hepatoprotective effects of Cyathea phalerata Mart. (Cyatheaceae). Basic \& Clinical Pharmacology \& Toxicology (Print), 103: 17-24.

Ighodaro, O.M; Akinloye, O.A. 2017. First line defence antioxidantssuperoxide dismutase (SOD), catalase (CAT) and glutathione peroxidase (GPX): Their fundamental role in the entire 
antioxidant defence grid. Alexandria Journal of Medicine: doi. org/10.1016/j.ajme.2017.09.001

Jaeschke, H.; McGil, M. R.; Williams, C.D.; Ramachandran, A. 2011. Current issues with acetaminophen hepatotoxicity. A clinically relevant model to test the efficacy of natural products. Life Sciences, 88: 737-745.

Karthivashan, G.; Arulselvan, P.; Tan, S.W.; Fakurazi, S. 2015. The molecular mechanism underlying the hepatoprotective potential of Moringa oleifera leaves extract against acetaminophen induced hepatotoxicity in mice. Journal of Functional Foods, 17:115-126.

Kisaoglu, A.; Ozogul, B.; Turan, M.I.; Yilmaz, I.; Demiryilmaz, I.; Atamanalp, S.S.; Bakan, E.; Suleyman, H. 2014. Damage induced by paracetamol compared with $\mathrm{N}$-acetylcysteine. Journal of the Chinese Medical Association, 77: 463-468.

Leandro, L.M.; Vargas, F.S.; Barbosa, P.C.S.; Neves, J.K.O.; Silva, J.A.; Veiga-Junior, V.F. 2012. Chemistry and biological activities of terpenoids from Copaiba (Copaifera spp.) oleoresins. Molecules, 17: 3866-3889.

Lima, S.R.M.; Veiga Junior, V.F.; Christo, H.B.; Pinto, A.C.; Fernandes, P.D. 2003. In vivo and in vitro studies on the anticancer activity of Copaifera multifuga Hayne and its fractions. Phytotherapy Research, 17: 1048-1053.

Malone, M.H. 1983. The pharmacological evaluation of natural products - general and specific approachs to screening ethnopharmaceuticals. Journal of Ethnopharmacology, 8, 127-147.

Manimaran, A.; Sarkar, S.N.; Sankar, P. 2010. Repeated preexposure or coexposure to arsenic differentially alters acetaminopheninduced oxidative stress in rat kidney. Environmental Toxicology, 26: 250-259.

Mesquita, L.M.S.; Colpo, K.D.; da Rocha, C.Q.; Gatte-Picchi, D.; Tangerina, M.M.P.; Zachello-Nunes, B.; Martins, M.B.G.; Vilegas, W. 2017. Anatomical differentiation and metabolomic profiling: A tool in the diagnostic characterization of some medicinal Plantago species. Brazilian Journal of Botany, 40: 801-810.

Misra, H.P.; Fridovich, I. 1972. The role of superoxide anion in the auto-oxidation of epinephrine and a simple assay for Superoxide dismutase. Journal of Biological Chemistry, 247: 3170-3175.

Mohar, I.; Stamper, B.D.; Rademacher, P.M.; White, C.C.; Nelson, S.D.; Kavanagh, T.J. 2014. Acetaminophen-induced liver damage in mice is associated with gender-specific adduction of peroxiredoxin-6. Redox Biology, 2: 377-387.

Mudge, G.H.; Gemborys, M.W.; Ruggin, G.G. 1978. Covalent binding of metabolites of acetaminophen to kidney protein and depletion of renal glutathione. Journal of Pharmacology and Experimental Therapeutics, 206: 218-26.

Nelson, D.L.; Cox, M.M. 2011. Princípios da Bioquímica de Lehninger. 5 ed. Artmed, Porto Alegre, 1273p.

Nelson, D.P.; Kiesow, L.A. 1972. Enthalphy of decomposition of hydrogen peroxide by catalase at $25^{\circ} \mathrm{C}$ (with molar extinction coefficients of $\mathrm{H}_{2} \mathrm{O}_{2}$ solution in the UV). Analytical Biochemistry, 49: 474-478.

Nelson, S.D.; Pearson, P.G. 1990. Covalent and non-covalent interactions in acute lethal cell injury caused by chemicals. Annual Review of Pharmacology and Toxicology, 30: 169-195.
Noguchi, A.; dos Reis, J.M.C.; Dias, C.S.; Epaminondas, W.A.; Azevedo, P.S.R.; Brito, M.V.H. 2002. Níveis séricos de aminotransferases, bilirrubinas e gama-glutamil transpeptidase após a admininstração de óleo de copaíba em ratos. Acta Cirúrgica Brasileira, 17: 130-134

Nuengchamnong, N.; Krittasilp, K.; Ingkaninan, K. 2009. Rapid screening and identification of antioxidants in aqueous extracts of Houttuynia cordata using LC-ESI-MS coupled with DPPH assay. Food Chemistry, 117: 750-756.

Olaleye, M.T.; Amobonye, A.E.; Komolafe, K.; Akinmoladun, A.C. 2014. Protective effects of Parinari curatellifolia flavonoids against acetaminophen-induced hepatic necrosis in rats. Saudi Journal of Biological Sciences, 21: 486-492.

Olaleye, M.T.; Rocha, B.T.J. 2008. Acetaminophen-induced liver damage in mice: Effects of some medicinal plants on the oxidative defense system. Experimental and Toxicologic Pathology, 59: 319-327.

Oshima-Franco, Y.; Franco, L.M. 2003. Biotransformação: importância e toxicidade. Saúde em Revista, 5: 69-76.

Ozcelik, E.; Uslu, S.; Erkasap, N.; Karimi, H. 2014. Protective effect of chitosan treatment against acetaminophen-induced hepatotoxicity. Kaohsiung Journal of Medical Sciences, 30: 286290.

Paiva, L.A.F.; Gurgel, L.A.; Campos, A.R.; Silveira, E.R.; Rao, V.S.N. 2004. Attenuation of ischemia/reperfusion-induced intestinal injury by oleo-resin from Copaifera langsdorffii in rats. Life Sciences, 75: 1979-1987.

Paiva, L.A.F.; Rao, V.S.N.; Gramosa, N.V.; Silveira, E.R. 1998. Gastroprotective effect of Copaifera langsdorffii oil-resin on experimental gastric ulcer models in rats. Journal of Ethnopharmacology, 62: 73-78.

Perlman, A.I.; Lebow, D.G.; Raphael, K.; Ali, A.; Simmons, L.A. 2013. A point-of-sale communications campaign to provide consumers safety information on drug-dietary supplement interactions: A pilot study. Health Communication, 28: 729-39.

Pieri, F.A.; Mussi, M.C.; Moreira, M.A.S. 2009. Óleo de copaíba (Copaifera sp.): histórico, extração, aplicações industriais e propriedades medicinais. Revista Brasileira de Plantas Medicinais, 11: 465-472.

Pisoschi, A.M.; Pop, A. 2015. The role of antioxidants in the chemistry of oxidative stress: A review. European Journal of Medicinal Chemistry, 97: 55-74.

Roe, J.H. 1954. Chemical determination of ascorbic, dehydroascorbic, and diketogulonic acids. In: Glick, D. (Ed). Methods of Biochemical Analysis. v.1. Interscience, New York, p.115-139.

Rosa, E.J.F.; Silva, M.H.; Carvalho, N.R.; Bridi, J.C.; Rocha, J.B.T.; Carbajo-Pescador, S.; Mauriz, J.L.; González-Gallego, J.; Soares, F.A. 2012. Reduction of Acute Hepatic damage Induced by Acetaminophen after Treatment with Diphenyl Diselenide in Mice. Toxicologic Pathology, 40: 605-613.

Sedlack, J.; Lindsay, R.H. 1968. Estimation of total, protein-bound, and nonprotein sulfhydryl groups in tissue with Ellman's reagent. Analytical Biochemistry, 25: 192-205.

Shanmugam, G.; Ayyavu, M.; Rao, D.M.; Devarajan, T.; Subramaniam, G. 2013. Hepatoprotective effect of Caralluma 
umbellate against acetaminophen induced oxidative stress and liver damage in rat. Journal of Pharmacy Research, 6: 342-345.

Shimoda, H.; Tanaka, J.; Kikuchi, M.; Fukuda, T.; Ito, H.; Hatano, T.; Yoshida, T. 2008. Walnut polyphenols prevent liver damage induced by carbon tetrachloride and D-galactosamine: Hepatoprotective hydrolysable tannins in the kernel pellicles of walnut. Journal of Agricultural and Food Chemistry, 56: 4444-4449.

Sousa, C.M.M.; Silva, H.R.; Vieira Jr., G.M.; Ayres, M.C.C.; Costa, C.L.S.; Araújo, D.S.; et al. 2007. Fenóis totais e atividade antioxidante de cinco plantas medicinais. Química Nova, 30: 351-355.

Souza, L.M.; Cipriani, T.R.; Iacomini, M.; Gorin, P.A.J.; Sassaki, G.L. 2008. HPLC/ESI-MS and NMR analysis of flavonoids and tannins in bioactive extract from leaves of Maytenusilicifolia, Journal of Pharmaceutical and Biomedical Analysis, 47: 59-67.

Stern, S.T.; Bruno, M.K.; Hennig, G.E.; Horton, R.A.; Roberts, J.C.; Cohen, S.D. 2005. Contribution of acetaminophen-cysteine to acetaminophen nephrotoxicity in CD-1 mice: I. Enhancement of acetaminophen nephrotoxicity by acetaminophen-cysteine. Toxicology and Applied Pharmacology, 202: 151-159.

Vásquez, S. P. F.; Mendonça, M. S.; Noda, S. N. 2014. Etnobotânica de plantas medicinais em comunidades ribeirinhas do Município de Manacapuru, Amazonas, Brasil. Acta Amazonica, 44: 457 - 472.
Veiga Jr., V. F.; Pinto, A. C. 2002. O gênero Copaifera L. Química Nova, 25: 273-286.

Veiga Junior, V.F.; Rosas, E.C.; Carvalho, M.V.; Henriques, M.G.M.O.; Pinto, A.C. 2007. Chemical composition and anti-inflammatory activity of copaiba oils from Copaifera cearensis Huber ex Ducke, Copaifera reticulata Ducke and Copaifera multijuga Hayne. A comparative study. Journal of Ethnopharmacology, 112: 248-254.

Verma, P. K.; Raina, R.; Sultana, M.; Prawez, S.; Jamwal, N. 2013. Hepatoprotective mechanisms of Ageratum conyzoides L. on oxidative damage induced by acetaminophen in Wistar rats. Free Radicals and Antioxidants, 3: 73-76.

Woisky, R.G.; Salatino, A. 1998. Analysis of própolis: Some parameters and procedures for chemical quality control. Journal of Apicultural Research 37: 99-105.

Yan, L.J.; Traber, M.G.; Packer, L. 1995. Spectrophotometric method for determination of carbonyls in oxidatively modified apolipoprotein B of human low-density lipoproteins. Analytical Biochemistry, 228: 349-351.

RECEIVED: 08/12/2017

ACCEPTED: 02/08/2018

ASSOCIATE EDITOR: Jorge David 